\title{
Promoting Citizenship Right through Street Law Projects
}

\author{
Soraya Rostami ${ }^{1}$, Hedayatollah Shenasaei ${ }^{1} \&$ Faramarz Shirvani $^{2}$ \\ ${ }^{1}$ Faculty of International Law, The China University of Political Science and Law, China \\ ${ }^{2}$ Faculty of International Law, National University of Malaysia, Malaysia \\ Correspondence: Hedayatollah Shenasaei, Department of Social and Development Sciences, Faculty of \\ International Law, The China University of Political Science and Law, Beijing, China. E-mail: \\ hedayat.shenasaei@yahoo.com
}

Received: August 13, 2013 Accepted: December 16, 2013 Online Published: January 26, 2014

doi:10.5539/ass.v10n4p273 URL: http://dx.doi.org/10.5539/ass.v10n4p273

\begin{abstract}
Citizens in any community who live in a particular area have (political, social and economic) rights in common that are determined by the way they play their parts in contribution to urban affairs. Citizen rights can be defined as a set of rights and responsibilities of the community versus their government. How these rights are exercised is determined by the international law. In this respect, the need is felt for the promotion and spreading of the citizenship culture, social capital and fulfillment of the advanced, progressive and well-developed community. The applied law education plan entitled 'Street Law' is an initiative within the framework of the program by collegiate law education Cliniques aiming at teaching law to the underprivileged and those who are ignorant of their rights and spreading law consciousness among the citizens. These rights are in direct association with the people's rights in social, cultural and political terms and are written and taught in simple language. Education department can play a vital role in this process, and the training can be delivered directly at schools or universities or in an informal manner they can be given to the community through the mass media (radio, television, newspapers and promotional movies).
\end{abstract}

Keywords: citizen ship, education, street law, development, human rights

\section{Introduction}

Globalization and world-wide technological and economic development has brought about many changes in both developed and underdeveloped nations. It can be said that liberalistic discourse in citizen rights is one of the most important issues of the contemporary society. In fact, in modern societies 'sustainable development' requires awareness of the people of the following two points: 1) Of their rights as citizens, and 2) Awareness of the necessity of establishing order and security in the community of human beings. These two are inseparably interrelated, so much so that one cannot imagine that the peoples' rights are respected in a community in which there are not standards for the deployment of social order and security. (Akbari, 2001)

Indeed, it is not without reason that Tomas Hobbs considers the 'social contract' to be the best solution for the reduction of tension and controversy, and achievement of social order and security in a way that public interest could be achieved in a peaceful and acceptable manner. He bases his reasoning on the fact that the people follow their own interests without worrying about whether meeting these interests could inflict serious harms to others. It is in the shadow of social security that the political rights and freedom of the people could be protected in an acceptable way against the totalitarian attitudes. (Mohammadi, 1999) On the other hand, it should be remembered that deployment of pervasive security in a human community requires the recognition and respecting the human rights and values and upbringing a well-informed generation that is faithful, respect-worthy, self-confident and responsible. In order for these goals to be attained, there must be a good understanding of the notion of 'citizen' and its position in the contemporary world. Indeed, the notion of 'citizen' does not materialize by the people having gathered together, but this takes place within the framework of the 'civil society'. (Vossoughi, 1998)

A civil society comprises groups and administrative institutions that are voluntary and independent and have been formed for the advancement of the interests of its members. To put it otherwise, the civil society's institutions serve as links between the public and the state who seek to perform their duties in a collective and independent way within the framework of law. The notion of 'modern citizen' is the result of the realization of an 
independent civil society who is responsible with respect to the public interest. Anyway, in order to achieve a dynamic motile society, its members should have an acceptable degree of political and social maturity to understand their basic rights as expressed in the domestic and international law. It is in line with this fact that educating the people and informing them of their rights and social responsibilities play an undeniable role in materializing the civil society and modern citizen. (Hassan, 1990)

\section{Applied SL Information, a Legal Clinic Project}

In 1972, SL was initiated as a research project in George Town Law Center. This nomenclature goes back to the following two facts: First, SL was taught to the pedestrians on the streets. Second, the rights taught to the people consisted of those needed by the people as they passed by the streets, markets, etc. (Mc Quoid, 1987) Among these rights, were rights related to accidents, thefts, insults and so forth. The name was also appealing to school boys. In the beginning, this project aimed at finding a way to transfer legal information to the teenagers in order to help them with their daily lives and to address their problems. (Rostas, 2007) The main idea behind this project was increased felony among teenagers that required the adoption of a preventive legal approach. (Mc Quoid, 1987)

This approach required that the criteria for the discrimination between good and bad be taught to the people and insights should be given to them to assess behaviors. In this way, youngsters could move towards social prevention of felonies. This kind of education in Law can create law consciousness among the students and furnish them with information on what to do when facing a legal problem. (Knowles, 1984) The project was carried out in this way: The people were talked to face to face on the streets and were reminded of their rights, for example, of how to treat a policeman when they are stopped by them, or what to do in legal terms when they go to a store, when they are attacked while walking along a street, when they are robbed of their purse, or when they have an accident.

\section{Human Rights and Education}

The UN not only considers education a basic right for all humans, but also considers it to be an effective tool for the promotion of human rights. Indeed, the goal followed by the promotion of human rights should be teaching skills, supply of scientific information and shaping behaviors towards the promotion of such a culture in which human rights is respected. Through teaching human rights, internationally recognized criteria of human rights become rooted among the local cultures of the nations. (Cohen, 2007) This viewpoint takes root from this philosophy that says, "Human rights are not foreign to any culture". Indeed, it can be considered as native to all nations. Since these rights are universal, nobody can pick and choose among these rights. Whether related to civil and cultural affairs, economic, political or social, they are inseparable and interdependent.

As the history has taught us, lack of human rights is something beyond denying the dignity of human beings and takes root in political poverty and violence, which is a problem with our world. (Nikfar, 1999) Human rights are indeed, rights that belong to human beings, because a human being is not identified with his faith, culture, language, race or nationality, but they are identified through their being a human. In this sense, 'right' is a concept that finds its meaning in the coexistence of human beings and in regulating and ordering it. For example, the right of education belongs to every citizen whether in childhood or in adulthood. Its responsibility is with the government that must provide the means of education with the aim of letting the people enjoy educational facilities. (Zakerian, 2002) In other words, a right becomes a human right when it is recognized as of a universal and moral value by the international community. Considering the implications of human rights as mentioned in the Declaration of Human Rights and the two of civil, political, economic and social conventions, one could say that these documents attribute the basic rights and freedoms to the intrinsic dignity of individuals and emphasize the commitment of the state parties to the observation of universal dignity in practice.

Instructions in human rights are based on the saying, "Prevention is better and cheaper than cure". Those who are aware of their rights feel responsible to their fellow human beings and avoid violating their rights. The importance of instructions in human rights has gone so far that the UN has named 1995-2004 time span decade of human rights education. In this time span, civil rights performers were prepared for the execution of the educational plans in civil rights. Many countries adapted their curriculums to this program as well as similar steps towards the promotion of human rights. Human rights education seeks the two following important objectives: One goal relates to education about human rights and the other is education for human rights. If the first goal is achieved the whole world will know more about human rights, and if the second goal is achieved, the informed people will have more power to exercise their human rights. UNESCO has named 2005 the year of human rights education in order to integrate human rights in different stages of education in line with the promotion of international understanding, participation and peace. The strategy adopted by UNESCO is a 
comprehensive approach to human rights. These rights are inseparable, and are interdependent with all cultural, economic, political and social rights of the citizens. (Izadi \& Mohammadi, 2007)

\section{The Role of Education in Developing Citizens}

The notion of education, in principle, means to lead. If we consider the mental consequences of the process of education, we can say that education is an activity that shapes the human mind in accordance with the social standards. (Dewey, 1960) The right of education ought to be considered part of the human rights that falls into both areas of civil-political and economic-social-cultural rights with elements from each of these areas. (Dova, 2004) Article 13 of International Covenant on Economic, Social and Cultural Rights on the right to education reads:

"The States Parties to the present Covenant recognize the right of everyone to education. They agree that education shall be directed to the full development of the human personality and the sense of its dignity, and shall strengthen the respect for human rights and fundamental freedoms. They further agree that education shall enable all persons to participate effectively in a free society, promote understanding, tolerance and friendship among all nations and all racial, ethnic or religious groups, and further the activities of the United Nations for the maintenance of peace".

In this respect, Paragraph 2 of Article 26 of the Declaration of Human Rights reads:

"Education shall be directed to the full development of the human personality and to the strengthening of respect for human rights and fundamental freedoms. It shall promote understanding, tolerance and friendship among all nations..."

Education plays an important role in preventing crimes and social anomalies. Therefore, the education system must elevate the awareness of the citizens of their individual and social rights, laws and regulations applicable in the society, in order to prevent crimes and social anomalies. It must be geared to the requirements of the nation in terms of life skills and age structure of the nation through developing plans for teaching law to youngsters. Any social advancement and development depends on education. Therefore, the approach adopted by the education system must be able to help the people in developing the right personality and become prepared to accept responsibilities they will undertake in the future. Also, education must address developments that take place in the society and facilitate them in the right way. (Joyce \& Weil, 2005) The right to full education for all is essential. The citizens of every community live in a certain political expanse with common rights defined according to their roles in urban, political, economic and social affairs. (Janos, 2004) Article 27 of the Universal Declaration of Human Rights reads:

"Everyone has the right freely to participate in the cultural life of the community, to enjoy the arts and to share in scientific advancement and its benefits."

Generally, education, if provided in a way that promotes participation, critical thinking and ideal seeking in humans can pave the way for substantial changes in the society. (Keyvanfar, 2004) Additionally, providing the right education to children will protect them against various social, economic, political and cultural threats that lie ahead of them. Though the shaping and development of character does not totally take place within the educational system, but the knowledge and insights provided at school constitute the best means to run a legitimate successful life.

\section{SL Program and Efficient Methods of Teaching Citizen Rights}

Implementation of teaching citizen rights to the public requires such teaching methods that are capable of communicating concepts, attitudes and skills in order to pave the way for the institutionalization of a legal culture and empower the people. The first step is to train teachers who are capable of using reflective-interactive method so that they can use this method in their teaching. Since the audience consists of a wide range of walks of life and formal and informal teaching environments, educators are to be university graduates at Law. (Cohen, 2007)

The main objective of this program is to teach Law to the underprivileged and those who are ignorant of their rights and cannot defend themselves. The SL program is determined to influence children and teenagers, and the method it has chosen is interactive-participative method. For example, in South Africa, SL allows students to leave the faculty and teach Law at prisons, correctional facilities, cultural houses, cultural centers, trade unions, and so forth in a simplified manner. In addition to text-book based presentation, some practical training will be given to these students in order to enable them to teach law step by step out of the faculty. For instance, the students of Law choose a real file and simulate it in the classroom. Cases on to murder, rape, and aids are the matters of interest to the students that can draw their attention. The students simplify these cases and teach them. 
(Mohammadi, 1999)

Assessments show that the result have proved very successful and has led to increased communicative skills in addition to self confidence among students. Students talk to the relieve seekers in correction facilities and prisons about crimes and the resultant effects and punishments and remind them of the consequences of their criminal behavior on the people and society. Evaluations of these programs show that they have proved effective and worked well with the society that has been under colonialism and exploitation for years. But the main focus of the SL program is on schools, that is, on children and the future generation in order to breed law-abiding citizens. (Babai, 2007)

The citizen education program seeks to develop free, tolerating and fair societies on the basis of citizenship rights and responsibilities in which the public values are respected, democracy is promoted, human rights are respected, law is ruling, and the common cultural heritage is enriched with all its diversity. Additionally, the people must believe that it is necessary that the human rights culture must be enhanced in terms of addressing general responsibilities on the basis of unity, equal opportunities, collaboration and social coherence. In this way, the way is paved for the development of citizens who are able to achieve freedom as a way of life that should be acquired and improved rather than a heritage passed on from past generations, and set a balance between their rights and responsibilities at national, regional, and international levels, look at education as a permanent learning experience and a useful tool that enables them to be prepared for active all out participation in the society and master their own fate through both formal and informal instructions.

Every citizen must achieve a minimum level of knowledge, skills, attitudes, and values in the right way to develop a good appreciation of democracy and its institutions, social and participation skills, the ability to communicate effectively with others and live together with them, respect equally the values of all human beings, use simple tools for the settlement of disputes, choose consciously with critical thinking, and contribute to freedom as a general expediency. In order to learn how to develop democratic citizens, we must deploy curriculums, experimental learning, and collective learning, problem solving and learning by doing. In this process, the educational content provided to citizens fall into the four individual, social, local and national categories. Table below shows these categories in detail:

Table 1.

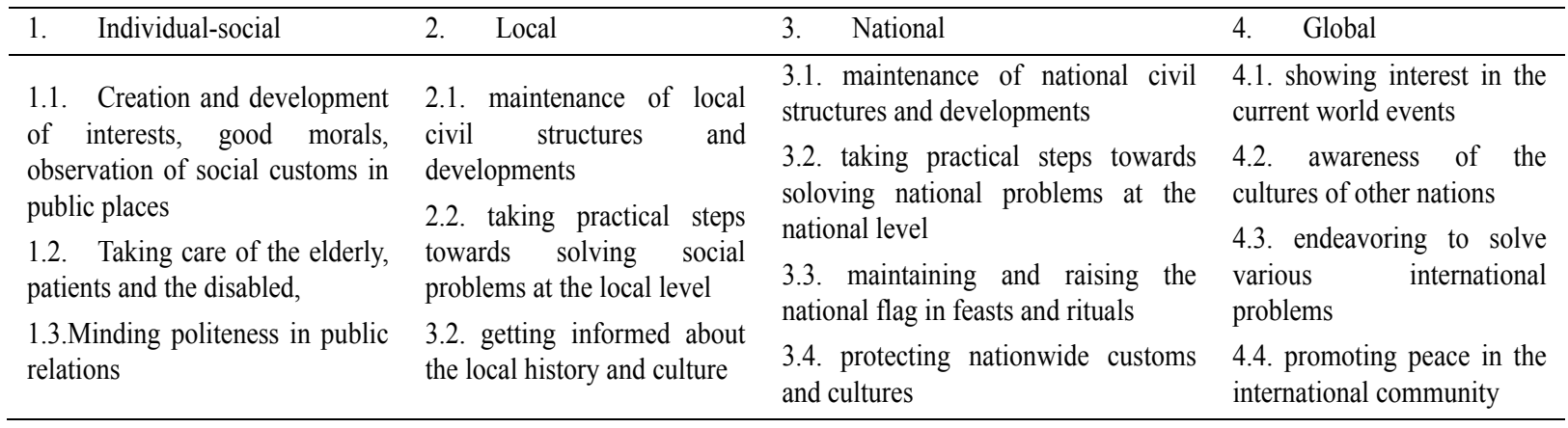

A survey carried out in Shanghai by Wing-Wah Law indicates that there is a significant difference between teachers' and students' opinions about the four levels mentioned above in terms of the selected and administered curriculums.

Participants must come to this important conclusion that school is a regular educating institution where human rights and pertinent responsibilities must be practiced, and educators should inculcate this belief through curriculums and collective practical learning programs, problem solving programs, and learning by doing programs. These curriculums must include rights and responsibilities both as special themes and as a principle that closely relates to other learning activities. In general, education for the purpose of practicing democratic citizenship must be helped by school, classroom and society. Traditionally, sometimes the people develop their love and devotion to their countries at school. Harvy has listed types of global awareness that all humans must develop as a prerequisite for citizenship development as follows:

1) Awareness in its general (global) sense.

2) Knowledge of ecological features,

3) Cross-cultural awareness, 
4) Knowledge about the dynamics ruling the contemporary world, and

5) Awareness of the global selection.

What Harvy's opinion implies is that global level must not be applied to dimensions that are easily memorized and communicated to students, but, conversely, ideals and values should be considered universal and global that the world citizens adhere to it. (Mahlstedt, 2003) Nasim believes that citizen rights education must take place at two levels: 1) Courses that help the students to achieve part of the educational goals and get informed about their dimensions and elements, and 2) Communication of the global citizen views. Nancy Bacon considers the following as the most important elements for the development of universal citizens (Nussbaum, 2002)

1) Knowledge of the society with respect to the world's economic systems. Knowledge of the society with respect to the world's political regimes,

2) Critical thinking skills in order to analyze, as well as issues that expand economic and political relationships,

3) Intercultural communication skills,

4) Opportunities for the exploitation of the people's participation as active citizens,

5) Opportunities for empathy with others, and

6) Forums in which people can talk to each other in a wide range of general issues.

In this respect, due attention should be paid to the efforts made by UNESCO that raises the interest in civil rights and a renaissance in citizen rights education in 1990 as the third wave of democracy. The UNESCO's strategy on teaching citizenship rights and human rights is based on a comprehensive approach to human rights. (Bacon, 2003) These rights are inseparable and are interdependent on all citizenship cultural, economic, political and social rights. In this viewpoint, the aim of the citizenship right is to publicize the information for building a general human rights culture using the knowledge and skills as well as framing positive attitudes and preparing learners with capabilities to follow and create social changes.

Increased pluralism at the global level has led to the encouragement of citizenship rights education. Citizens of every society live in a certain political expanse with common rights that are determined by the level of their participation in urban, political, social and economic affairs. Citizenship education systems go beyond simple models based on human rights and responsibilities and are after shaping the relationship of the people with each other and promotion of the spirit of balance and peace. In this respect, the educational system of a country plays a vital role the education and upbringing the citizens. Though the shaping and development of character does not totally take place within the educational system, but the knowledge and insights provided at school constitute the best means to run a legitimate successful life. In fact, education through the formal institutions is one of the most important and objective parts of the upbringing of a human being the effects of which can be observed and debated in a comprehensive manner.

On the other hand, the dynamicity and livelihood of a community depends on the active participation of the younger generation in its various affairs. A generation who, consciously and with a developed personality, is able to have an all-out participation in its society and play its citizenship role in the right way, and who is able to think reasonably in response to problems and make wise decisions towards solving them. Therefore, citizenship education consists of the increasing of the knowledge of learners of their citizenship and human rights, helping them to acquire necessary skills and develop values that have been determined by a community who considers them to be important and essential, as well as the understanding of complexities that exist at global, national and local levels. These teachings are in the first place responsibilities of formal educational systems because of the long-term presence of a child at school, and in the second place, are borne by informal educational systems.

\section{Conclusion}

This is an undeniable principle that social progress and development of capabilities and competencies of any individual depends on comprehensive and well-developed education and training. Admitting this fact, mechanisms and methods developed to educate community members play a vital role, so much so that full and coordinated growth of the people's personality and preparing them for the acceptance of social responsibilities depends on the education methods one has to go through from childhood to adulthood. The SL plan is an applied method for institutionalizing the citizenship law culture in a human community which is in pursuit of educating the people in globally accepted values, such as respecting the other people's rights and ideas, elevating the tolerance level of the opponent values and increasing the responsibility level of the people against other fellow human beings in a plain and simple way and far from intricacies and complications.

Indeed, this plan has been developed with the presupposition that the people who are aware of their own rights 
feel more responsible against each other and avoid violating the other people's rights. The most important result of this initiative is to institutionalize citizen rights among learners, particularly the young generation, and it can prevent crimes and felonies to happen. Additionally it creates the opportunity for citizens to be aware of their rights and be able to defend themselves against non-democratic behaviors of the governors or even non-executive ordinary people. Also, this plan provides suitable grounds for the elevation of involvement in social affairs and inspires an altruistic spirit among citizens so that they won't consider each other enemies or deviated elements but they represent others as fellow humans but with different vies, attitudes and ideals from themselves. It is enough for this project to be 'understood' by the public without the need for incentives and publicizing the ideas and values concerned with it.

\section{References}

Akbari, L. (2001). A study on preventive measures from teenager felony in international law. Tehran, Tehran University Press.

Andrew, M. (2003). Global Citizenship Education in Practice: An Explanation of Teachers in the United World Gollegs. Monograph International Comparative Education School of Education, Stanford University.

Babai, E. (2007). Foundations of Citizenship Rights in Islam. Citizenship Rights Articles Collections (2nd ed.). Nashr e Markaz Press.

Cohen, B., \& Orbuch, T. L. (1989). Introduction to Sociology (M. Tavassoli, Trans.) (1st ed.). Tehran University Press (original from McGraw-Hill).

Hassan Amid, Persian Culture (1990). The Journal of Amir Kabir, 3, 795. Tehran.

Heyman-Doat, A. (2004). Libertes publiques ET droits de l'homme (Yusuf Mowla'ii and Rasheed Bornak, Trans.). Tehran University Press.

Izadi, S., \& Mohammadi, A. A. (2007). Citizenship Education, Human Rights and Social Responsibility in the Education System. Articles Collections of Citizenship Rights, Nashr e markaz Press.

John, D. (2004). Democracy and Education: An Introduction to the Philosophy of Education. NuVision Publications.

Joyce, B., Weil, M., \& Calhoun, E. (2008). Models of Teaching. Pearson/Allyn and Bacon Publishers.

Keyvanfar, S. (2004). Resistance to Law (the Rule of law and Society). Tehran, Center for Human Rights Studies.

Knowles, M. (1984). The Adult Learner: A Neglected Species (3rd ed.). Houston, TX: Gulf Publishing.

Law, W. W. (2007). Globalization, City Development and Citizenship Education in China's Shanghai. International Journal of Educational Development, $\quad 27(1), \quad 18-38$. http://dx.doi.org/10.1016/j.ijedudev.2006.04.017

Marian, B. R. (2010). Clinical Legal Education in Central and Eastern Europe: Selected Case Studies. Oxford Scholarship Online.

Martha, N. (2002). Education for citizenship in an era of Global Connection, Studies in philosophy and education, 21(4-5), 289-303. Kluwer Academic Publisher.

McQuoid-Mason, D. (1987). Introduction to South African law and the legal system (Street law). Association of Law Societies of South Africa and Centre for Socio-Legal Studies, University of Natal.

McQuoid-Mason, D. (2008). Street Law as a Clinical Program: The South African Experience with Particular Reference to the University of KwaZulu-Natal, 17(1). Griffith Law Review 27.

Mohammadi, M. (1999). Iranian civil society: Theorical bases and obstacles. Tehran, Nashr e markaz Press.

Nancey, B. (2003). Redefining Citizenship for Our Multicultural World, New Horizons for Learning. Retrieved from http://www.newhorizons.org/strategies multicultural World

Nikfar, M. R. (1999). Violence (2nd ed). Human Rights and Civil Society, Tehran, Tarh-e No Press.

Symonides, J. (2004). Human rights: New dimensions and challenges (Dr Mohamed Ali Shyrkhany, Trans.) (1st and 2nd Volumes). Tehran University Press.

Vossoughi, M., \& Nikkholgh, A. (1998). Foundations of Sociology. Tehran, Etelaat Press.

Zakerian, M. (2002). Human Rights in the New Millennium. Tehran, Majd Press.

\section{Copyrights}

Copyright for this article is retained by the author(s), with first publication rights granted to the journal.

This is an open-access article distributed under the terms and conditions of the Creative Commons Attribution license (http://creativecommons.org/licenses/by/3.0/). 